\title{
The Relationship between Interest Rate and Economic Growth in Nigeria: ARDL Approach
}

\author{
Adegoke, Temitope Damilola, Azeez, Bolanle Aminat (Ph.D), Ogiamien, Fidelis Omoruyi, \\ Osasona, Viscker Adedeji \\ Department of Finance, Ekiti State University, Ado-Ekiti, Nigeria
}

\begin{abstract}
This study examined the relationship between interest rate and economic growth in Nigeria, using secondary time series data. Data was collected from various issues of the Central Bank of Nigeria Statistical Bulletin and the National Bureau of Statistics. The study made use of the Augmented Dicker-Fuller (ADF) unit root tests and it was discovered that the variables were not in the same order at level, hence, the use of Autoregressive Distribution Lag (ARDL). The GDP was used to proxy economic growth as dependent variable, while Lending Rate (LR), Exchange Rate (EXC) and Treasury bill Rate (TB) were used as independent variables. It was discovered during the findings that there is a very strong long run relationship among the dependent and the independent variables and the speed of adjustment on equilibrium was set at $\mathbf{7 9 . 4 \%}$. The result also discovered that there is a negative relationship between the lending rate and the GDP though, statistically insignificant, while positive relationship exists between the GDP, Treasury bill rate and Exchange rate. The paper recommended that the Lending rate has some policy implication on economic growth in Nigeria and the monetary authority should handle it with care and the government should find a way of making the Treasury bill rate more attractive to the investing public.
\end{abstract}

Key words: Lending rate, Treasury bill rate, Exchange rate, Investment and Gross Domestic Product (GDP)

\section{INTRODUCTION}

$\mathrm{P}$ rior to the deregulation of the banking sector or industry in Nigeria, in 1986, interest rates were administratively determined by the Central Bank of Nigeria (CBN), and there were ceilings on both deposits and lending rates. During this period most developing countries like Nigeria intervened substantially in the financial sector by setting interest rates and directing the allocation of credit in the economy, so as to accelerate the most desired development (Lyndon and Peter, 2016).

This was no longer yielding any positive result as some stage as the financial institutions in the country could no longer mobilize loanable funds for investment. Therefore, financial sector reforms were introduced to correct the problem caused by financial repression, and such reforms include interest rate liberation and the removal of ceiling and other controls on credit allocation (Obamuyi and Olorunfemi, 2011). Interest rate directly affect lending and borrowing rate because higher interest rate make servicing of loans more costly. As interest rate drops, consumer spending increases, and this in turn stimulate economic growth.
The researchers' motivation to study this area of the economy hinges on the fact that interest rate is one of the most essential aspects of Nigerian economic system that influence the cost of borrowing, and borrowing is an imperative source of financing businesses and investment which may lead to economic growth. Moreover, interest rate affects the return on savings. If the interest rate to be paid on savings is encouraging, individuals will be willing to save more which will pave way for loanable funds for investment and ultimately lead to economic growth.

The researcher's choice of 1986 was suggested-out of the fact that there was a total and general financial reform in the country which relied on the market forces and the main objective was the elimination of financial repression in order to improve the incentive structure and ensure productive efficiency in the economy (Obamuyi and Olorunfemi, 2011). It has been asserted that high interest rate discourage investment and as a result affected economic growth and also, high rate of interest increase the cost of borrowing which could lead to reduction of output and create unemployment rate in the country.

A number of empirical reviews had been done in the past on the current work with consensus yet to be reached among the several findings by the researchers. In the work of Lyndon and Peter, (2016), on which this paper is anchored, they made use of Interest rate, Inflation rate and Exchange rate but not Treasury bill rate. The growth in the economy should not only be seen as the main responsibility of the private sector alone but also, the contributions of the government at all levels should also be encouraged. This can be achieved by the improvement in the government expenditures which can be triggered by the improvement in the government revenues such as selling of Treasury bill. Therefore, it is against this backdrop that this research work attempted to bridge the gap and introduce Treasury bill as one of the variables of interest rate, and contributes to the existing body of knowledge. Thus, the broad objective of this work is to find the relationship between interest rate and economic growth in Nigeria from 1986 to 2017 . The study introduced Treasury bill and Lending rate in order to have a robust analysis.

The research is expected to answer the following questions:

i. What is the effect of Treasury bill rate on economic growth in Nigeria? 
ii. What is the impact of Lending rate on the economic growth in Nigeria?

iii. How does the exchange rate affect the economic growth in Nigeria?

In this regard, the paper has the following objectives;

i. To examine the effect of Treasury bill rate on the economic growth in Nigeria

ii. To determine the impact of lending rate on the economic growth in Nigeria

iii. To know the extent at which the exchange rate affect the economic growth in Nigeria

The rest of the work is hereby structured as follows: section two provided the review of empirical literature, while section three presents the research methodology and sources of data. Section four presented the empirical results and discussion, while section five highlighted the conclusion and recommendations offered based on our findings.

\section{REVIEW OF RELATED LITERATURE}

The problem of interest rate and economic growth has been on the front burner of the economists over a long period of time. This part of the work presents the review of previous empirical literature to provide a background for examining the relationship between interest rate and economic growth in Nigeria using time series data from 1985 to 2017.

\section{i. Lending Rate}

Kenneth (2008) defines the lending rate as the charge that a lender charges a borrower. The term "lending rate" is synonymous with the term "Interest rate". Though, this rate can be a very important factor in determining what the final cost of the loan will be, there are others that should not be ignored such as Treasury bill rate.

\section{ii. Economic Growth}

Economic growth refers to an increase in the productive capacity of an economy as a result of which the economy is capable of producing additional quantities of goods and services. GDP is a measure of the value of the goods and services produced in the economy irrespective of who owns the factors of production used to produce these goods and services (Kiragu, 2015)

\section{iii. Treasury Bill}

Treasury bills are short-term sovereign debt securities maturing in one year or less. They are sold at discount and redeemed at par. The Federal Government of Nigeria, through the Central Bank of Nigeria, issues Nigerian Treasury Bills to provide short-term funding for government budget deficit. Treasury bills are discount instruments and they are so called because the investor gets its interest upfront. This means that the interest promised on a Treasury Bill instrument is payable on the very day the investment commences. For example, if a Treasury bill promises $10 \%$ rate per annum and an investor wants to put in $\mathrm{N} 100,000$, the investor pays only N90,000 from the day of investment but gets back N100,000 at maturity. The maturity value $(\mathrm{N} 100,000)$ is referred to as face value while the initial investment $(\mathrm{N} 90,000)$ is discount value.

Lyndon and Peter (2016) examined the relationship between interest rate and economic growth in Nigeria from 1986 to 2014. Data was collected from various issues of the Central Bank of Nigeria Statistical Bulletin and the National Bureau of Statistics. The study employed Augmented Dicker-Fuller (ADF) unit root tests as well as Johansen integration test followed by Error Correlation Model (ECM) approach and found that interest rate is inversely related to economic growths, but the relationship is statistically insignificant. They recommended that monetary authorities should adopt appropriate polices that would promote and stimulate economic growth in Nigeria.

The aim of the study was to determine the effect of inflation rate, exchange rate and deposit interest rates on the gross domestic product of the country. The data for the study was obtained from the statistical bulletin of the Central Bank of Nigeria from 1980-2016. The research design adopted for the study was the ex-post facto research design. It was found that INF and EXR have negative and insignificant effect on GDP. Also it was found that DIR has positive and significant relationship with GDP. The study generally concludes that interest rate has a negative and insignificant relationship with GDP.

Barry (2014) explores the long-term determinants of interest rates, and, in particular, the relationship between variations in interest rates and the rate of economic growth. Is there a positive correlation, as suggested by standard growth theory, or is the role of economic growth overshadowed by a larger array of domestic and foreign influences. Data from a number of large economies are used to demonstrate the influence of foreign interest rates in an increasingly globalized world capital market. A method is developed to adjust both long and short-term interest rates for expected inflation. The paper suggests that capital markets are highly integrated at the global level and that it makes little sense to model, analyze, or forecast interest rates within a closed-economy framework.

Acha and Acha (2011) examine the implications of interest rate for savings and investment in Nigeria. It used data obtained from the Central Bank of Nigeria (CBN). Data were analyzed using Pearson's Correlation Coefficient and regression. Evidence showed interest rate as a poor determinant of savings and investment indicating that bank loans are mostly not used for productive purposes. Therefore, bank loans should be channeled to productive investments if interest is to play its catalytic role in the Nigerian economy

Richard (2018) examined the Effect of Interest rate mechanism on Economic Development of Nigeria (19862016). The research work selected Nigeria as its sample and used the OLS, Co-integration, Granger-causality and Error Correction model data Analysis techniques, to test the Effect of the independent variables (interest rates and Monetary 
policy rates) on the dependent variable, economic development (proxy by Human Development index) and tested at the $5 \%$ level of significance. The study concludes that discount rate instruments such as interest and monetary policy rates have significant effect on economic development and recommends amongst others that discount rates should be environment and Business-friendly and predictable in line with prevailing economic dictates and as much as feasible government fiat should be reduced in arriving at monetary rates.

Obamuyi (2009) investigated the relationship between interest rate and economic growth in Nigeria, using secondary time series data for the period 1970 - 2006. He employed cointegration technique and error correction model to capture both the long-run and short-run linear causality relationship between the study variables, and the analysis of data. The result showed that real lending rates have significant effect on economic growth and there also exist a unique long-run relationship between interest rate and economic growth.

In Udoka and Roland (2012), they evaluated the effect of interest rate fluctuation on economic growth of Nigeria for the period 1970 - 2010, using the ordinary least square multiple regression analytical technique. Their analysis spanned two time periods; before and after the interest rate deregulation regimes. Their ex-post facto research design used secondary time series panel data collected from the Central Bank of Nigeria (CBN) statistical Bulletin. The findings revealed that interest rate had an inverse relationship with economic growth in Nigeria.

\section{METHODOLOGY}

This study examines the relationship between interest rate and the economic growth in Nigeria. In order to have discussion on the analysis of data and answer the various research questions earlier asked, the Treasury bill is introduced with lending rate and exchange rate as independent variables, while the real GDP is used as the dependent variable. So, the study looked at the relationship between the independent variables and the dependent variable in Nigeria using the time series Data spanning from 1986-2017.

\subsection{Sources of Data}

This study used annual data for the period covering 1986 to 2017, obtained from the Statistical Bulletin of the Central Bank of Nigeria (CBN) and the National Bureau of Statistics (NBS). The availability of the relevant required data relating to the study variables informed the choice of the study period. Besides, this source of data is considered reliable and dependable.

\subsection{Data Analysis Technique}

The study made use of unit root test, descriptive statistics and auto regressive distributed lag test to analyze data collected for the period $1986-2017$.

\subsection{Model Specification}

This research work adopted the model of Lyndon and Peter (2016) with some changes in the variables through the introduction of Lending rate and Treasury bill rate.

$\log G D P=f(\log L D R, \log T B R, \log E X C)$

The above regression model was explicitly translated into a regression equation as stated below:

$G D P=\alpha+\beta 1 L D R+\beta 2 T B R+\beta 3 E X C+e$

Where:

GDP is Gross Domestic Product

LDR is Lending Rate

TBR is Treasury Bill Rate

EXC is Exchange Rate

$\alpha=$ is the constant term

$\beta 1, \beta 2, \beta 3=$ are the coefficients of the independent variables

$e=$ error term of the equation

\subsubsection{Analyses and Interpretation of Findings}

The empirical analysis started with the analysis of testing the variables of interest using Augmented Dickey Fuller (ADF) unit root test so as to know whether the variables are stationary or non-stationary at level or at first difference. The result, as presented below, in the table gives a clear ADF analysis of the variables at first difference.

Table 1

\begin{tabular}{|c|c|c|c|c|c|c|}
\hline $\begin{array}{c}\text { Serie } \\
\mathrm{s}\end{array}$ & $\begin{array}{c}\text { ADF t- } \\
\text { statistic } \\
\mathrm{s}\end{array}$ & $\begin{array}{c}5 \% \\
\text { Critical } \\
\text { value }\end{array}$ & $\begin{array}{c}10 \% \\
\text { critical } \\
\text { value }\end{array}$ & $\begin{array}{c}\text { Order } \\
\text { of } \\
\text { Integr } \\
\text { ation }\end{array}$ & Prob. & Remark \\
\hline $\begin{array}{c}\text { LogG } \\
\mathrm{DP}\end{array}$ & $\begin{array}{c}0.5110 \\
53\end{array}$ & $\begin{array}{c}2.9639 \\
72\end{array}$ & $\begin{array}{c}2.62100 \\
7\end{array}$ & $1(1)$ & 0.0815 & $\begin{array}{c}\text { Non- } \\
\text { Stationar } \\
\text { y Level }\end{array}$ \\
\hline $\begin{array}{c}\text { LogL } \\
\mathrm{R}\end{array}$ & $\begin{array}{c}5.0062 \\
71\end{array}$ & $\begin{array}{c}2.9604 \\
11\end{array}$ & $\begin{array}{c}2.61916 \\
0\end{array}$ & $1(0)$ & 0.003 & $\begin{array}{c}\text { Stationar } \\
\text { y at Level }\end{array}$ \\
\hline $\begin{array}{c}\text { LogE } \\
\mathrm{XC}\end{array}$ & $\begin{array}{c}2.1543 \\
09\end{array}$ & $\begin{array}{c}2.9604 \\
11\end{array}$ & $\begin{array}{c}2.61916 \\
0\end{array}$ & $1(1)$ & 0.2261 & $\begin{array}{c}\text { Non- } \\
\text { Stationar } \\
\text { y Level }\end{array}$ \\
\hline $\begin{array}{c}\text { LogT } \\
\mathrm{B}\end{array}$ & $\begin{array}{c}2.4360 \\
-\end{array}$ & $\begin{array}{c}2.9604 \\
-\end{array}$ & $\begin{array}{c}2.61916 \\
-\end{array}$ & $1(1)$ & 0.1406 & $\begin{array}{c}\text { Non- } \\
\text { Stationar } \\
\text { y Level }\end{array}$ \\
\hline
\end{tabular}

Source: E-view 9 result

From table 1 above, the Augmented Dickey Fuller (ADF), unit root test indicated that all the variables were non stationary at level except the lending rate (LR). From the table, the LogTR ADF f-statistics has -5.006271 and higher than the critical value at $5 \%$ and $10 \%$ in absolute term which means it is stationary, but, others, LogGDP, LogEXC and LogTB are $-0.511053,-2.154309$, and -2.436035 are lesser than their critical values in absolute terms. 
Table 2: Descriptive Statistics Result

\begin{tabular}{|c|c|c|c|c|}
\hline & $\begin{array}{c}\text { LOG(GD } \\
\text { P) }\end{array}$ & LOG(EXC) & LOG(LR) & LOG(TB) \\
\hline Mean & 10.34841 & 3.835154 & 2.914616 & 2.561949 \\
\hline Median & 10.20543 & 4.643234 & 2.888425 & 2.575964 \\
\hline Maximum & 11.14484 & 5.722931 & 3.394508 & 3.292126 \\
\hline Minimum & 9.631547 & 0.703098 & 2.351375 & 1.504077 \\
\hline Std. Dev. & 0.518723 & 1.417455 & 0.195728 & 0.385252 \\
\hline Skewness & 0.273454 & -0.5827 & 0.026155 & -0.82425 \\
\hline Kurtosis & 1.579744 & 2.030318 & 4.648559 & 3.567709 \\
\hline Jarque-Bera & 3.088316 & 3.064573 & 3.627312 & 4.053113 \\
\hline Probability & 0.213492 & 0.216041 & 0.163057 & 0.131789 \\
\hline Sum & 331.1492 & 122.7249 & 93.26770 & 81.98237 \\
\hline $\begin{array}{c}\text { Sum Sq. } \\
\text { Dev. }\end{array}$ & 8.341267 & 62.28452 & 1.187590 & 4.600996 \\
\hline $\begin{array}{c}\text { Observation } \\
\text { s }\end{array}$ & 32 & 32 & 32 & 32 \\
\hline
\end{tabular}

In the Table 2 above, the Descriptive analysis result shows that, the LogGDP has an mean value of 10.3 and which moves from 9.6 to 11.1 with the standard deviation of 0.52 . The skewness, kurtoses and the JarqueBera are $0.27,1.58$ and 3.01 respectively.

The skewness is zero, which means that the distribution is normal and the Kurtoses is less than 3 and positive, which implies that the value is leptokurtic. The Jarque-bera is 3.01 with the probability of 0.2 which is higher than the significant level of 0.05 . This implies that the value is normally distributed.

On the $\operatorname{LogEXC}, \operatorname{LogLR}$ and the $\log \mathrm{TB}$, the average values are $3.8,2.9$, and 2.6 , which ranges from 0.7 to $5.7,2.4$ to 3.4 and 1.5 to 3.3 respectively. The Jarque-bera values are 3.06, 3.6 and 4.1 for $\operatorname{LogEXC}, \operatorname{LogLR}$ and $\log \mathrm{TB}$ respectively. These are with the probability vales of $0.2,0.16$, and 0.13 respectively.

Source: E. view 9 result

Table 4 (ARDL) Lag Selection Criteria.

\begin{tabular}{|c|c|c|c|c|c|c|}
\hline \multicolumn{7}{|c|}{ VAR Lag Order Selection Criteria } \\
\hline \multicolumn{7}{|c|}{ Endogenous variables: LOG_GDP LOGEXC LOGLR LOGTB } \\
\hline \multicolumn{7}{|c|}{ Exogenous variables: $\mathrm{C}$} \\
\hline \multicolumn{7}{|c|}{ Date: 06/29/19 Time: 09:34 } \\
\hline \multicolumn{7}{|c|}{$\begin{array}{c}\text { Sample: } 19862017 \\
\text { Included observations: } 28\end{array}$} \\
\hline Lag & $\log \mathrm{L}$ & LR & FPE & AIC & $\mathrm{SC}$ & HQ \\
\hline 0 & -33.95004 & NA & 0.000177 & 2.710717 & 2.901032 & 2.768898 \\
\hline 1 & 79.61615 & $186.5730 *$ & $1.69 \mathrm{e}-07 *$ & -4.258296 & $-3.306722^{*}$ & $-3.967390 *$ \\
\hline 2 & 88.00886 & 11.39011 & $3.15 \mathrm{e}-07$ & -3.714919 & -2.002084 & -3.191288 \\
\hline 3 & 111.8302 & 25.52287 & $2.23 \mathrm{e}-07$ & -4.273586 & -1.799492 & -3.517231 \\
\hline 4 & 136.4488 & 19.34317 & $1.93 \mathrm{e}-07$ & $-4.889199 *$ & -1.653846 & -3.900119 \\
\hline \multicolumn{7}{|c|}{ * indicates lag order selected by the criterion } \\
\hline \multicolumn{7}{|c|}{ LR: sequential modified LR test statistic (each test at $5 \%$ level) } \\
\hline \multicolumn{7}{|c|}{ FPE: Final prediction error } \\
\hline \multicolumn{7}{|c|}{ AIC: Akaike information criterion } \\
\hline \multicolumn{7}{|c|}{ SC: Schwarz information criterion } \\
\hline \multicolumn{7}{|c|}{ HQ: Hannan-Quinn information criterion } \\
\hline
\end{tabular}

Table 5 Autoregressive distributed Lag.

\begin{tabular}{|c|c|c|c|c|}
\hline Variable & Coefficient & $\begin{array}{c}\text { Std. } \\
\text { Error }\end{array}$ & t-Statistic & Prob. \\
\hline C & 0.838672 & 0.332554 & 2.521913 & 0.0198 \\
\hline $\begin{array}{c}\text { D(LOG_GDP(- } \\
\text { 1) }\end{array}$ & 0.333100 & 0.190168 & 1.751603 & 0.0944 \\
\hline $\begin{array}{c}\text { D(LOGEXC(- } \\
\text { 1)) }\end{array}$ & 0.005682 & 0.020371 & 0.278896 & 0.7831 \\
\hline D(LOGLR(-1)) & -0.050387 & 0.033102 & 1.522193 & 0.1429 \\
\hline
\end{tabular}

\begin{tabular}{|c|c|c|c|c|}
\hline D(LOGTB(-1)) & 0.019680 & 0.021208 & 0.927919 & 0.3640 \\
\hline LOG_GDP(-1) & -0.071292 & 0.029027 & -2.456102 & 0.0228 \\
\hline LOGEXC(-1) & 0.026462 & 0.010927 & 2.421764 & 0.0246 \\
\hline LOGLR(-1) & -0.036734 & 0.053225 & -0.690166 & 0.4976 \\
\hline LOGTB(-1) & -0.025089 & 0.020335 & -1.233771 & 0.2309 \\
\hline
\end{tabular}

Source: E-view 9 result 
In the above table, it can be deduced that there is a positive relationship between the independent variables, except the lending rate and the GDP, the dependent variables in the short run. This is expected though, because, the lending rate, exchange rate and the Treasury bill rate are motivating factors of investment. This shows that, the better the lending, exchange and treasury bill rates, the better the investments and ultimately will improve the GDP.

Table 6 Autoregressive Distributed Lag

\begin{tabular}{|c|c|c|c|c|}
\hline Variable & Coefficient & Std. Error & $\begin{array}{c}\mathrm{t}- \\
\text { Statistic }\end{array}$ & Prob. \\
\hline C & 0.459767 & 0.389568 & 1.180197 & 0.2525 \\
\hline $\begin{array}{c}\text { D(LOG_GDP(- } \\
\text { 1) })\end{array}$ & 0.822004 & 0.323947 & 2.537465 & 0.0201 \\
\hline $\begin{array}{c}\text { D(LOGEXC(- } \\
\text { 1) })\end{array}$ & 0.026905 & 0.024150 & 1.114056 & 0.2792 \\
\hline D(LOGLR(-1)) & -0.070170 & 0.039620 & 1.771075 & 0.0926 \\
\hline D(LOGTB(-1)) & 0.001413 & 0.022805 & 0.061948 & 0.9513 \\
\hline LOG_GDP(-1) & -0.037669 & 0.033514 & $\begin{array}{c}- \\
1.123977\end{array}$ & 0.2750 \\
\hline LOGEXC(-1) & 0.013465 & 0.013069 & 1.030252 & 0.3158 \\
\hline LOGLR(-1) & -0.029973 & 0.058544 & $\begin{array}{c}- \\
0.511971\end{array}$ & 0.6146 \\
\hline LOGTB(-1) & -0.011929 & 0.020961 & $\begin{array}{c}- \\
0.569104\end{array}$ & 0.5760 \\
\hline ECM(-1) & -0.794636 & 0.431586 & $\begin{array}{c}- \\
1.841199\end{array}$ & 0.0813 \\
\hline
\end{tabular}

Source: E-view 9 result

\begin{tabular}{|c|c|}
\hline R-squared & 0.611983 \\
\hline Adjusted R-squared & 0.428186 \\
\hline S.E. of regression & 0.027528 \\
\hline Sum squared resid & 0.014398 \\
\hline Log likelihood & 69.16650 \\
\hline F-statistic & 3.329661 \\
\hline Prob(F-statistic) & 0.013072 \\
\hline
\end{tabular}

In the table 6 above, with the proper lag selection of one (1) made, the ECM is negative and significant at $10 \%$. The speed of adjustment towards the equilibrium is $79.4 \%$. Since it is negative and significant at $10 \%$, this shows that the whole system can get back to long run equilibrium at the speed of 79.4. The $\mathrm{R}^{2}$ value of 0.61 means that $61 \%$ of the model is well explained by the explanatory variables, this suggests that our model is adequate and is a good fit.

The result of the short run analysis has a positive influence on the GDP except the lending rate that has an inverse relationship with the GDP. This shows that for the GDP to increase, there should be a reduction in the lending rate, and if there is an increase in the lending rate, the investment will reduce and at the same time cause the GDP to go down.
Table 7 ARDL Bound Test

\begin{tabular}{|c|c|c|c|}
\hline \multicolumn{3}{|c|}{ Wald Test: } & \\
\hline \multicolumn{3}{|c|}{ Equation: Untitled } & \\
\hline Test Statistic & Value & df & Probability \\
\hline F-statistic & 7.597275 & $(4,21)$ & 0.0658 \\
\hline Chi-square & 10.38910 & 4 & 0.0344 \\
\hline Source: E-View 9
\end{tabular}

From the above table, the F-statistics is 7.597275 which is clearly more than the Pasaran upper and lower bound of 4.8 and 3.7 respectively. This shows that there is a long run relationship among the variables.

Table 8 Breusch-Godfrey Serial Correlation LM Test

\begin{tabular}{|c|c|c|c|}
\hline F-statistic & 1.966327 & Prob. F(2,19) & 0.1674 \\
\hline $\begin{array}{c}\text { Obs*R- } \\
\text { squared }\end{array}$ & 5.144612 & $\begin{array}{c}\text { Prob. Chi- } \\
\text { Square(2) }\end{array}$ & 0.0764 \\
\hline
\end{tabular}

Source: E-view 9 result

The above table shows the variables have no serial correlation.

\section{CONCLUSION AND RECOMMENDATIONS}

The study examined the relationship between interest rate and economic growth in Nigeria using secondary time series data for the period $1986-2017$. The study introduced three (3) independent variables, such as Lending rate, Exchange rate and Treasury bill rate. The study therefore investigated the relationship between lending rate, Treasury bill rate, exchange rate and gross domestic product in Nigeria. Data for the study was collected from National Bureau of Statistic (NBS) and various Statistical Bulletins of the Central Bank of Nigeria $(\mathrm{CBN})$.

The analysis started with testing the variables with Augmented Dickey Fuller (ADF) unit root test because it's a time series data. It was discovered that all the variables were non stationary at level except the lending rate. Therefore, there is need for the introduction of Autoregressive distribution lag (ARDL). The Bound test shows that there is a very strong long-run relationship among the variables. While the (ARDL) shows there is negative relationship between lending rate and the gross domestic product (GDP),this was in line with the work of (Lyndon and Peter, 2016), while exchange rate and Treasury bill rate also possess a strong positive relationship with the GDP in the short run.

Based on the following findings, the study recommended as follows

i. That the Lending rate has some policy implication on economic growth in Nigeria, this is made possible because if there is an increase in Lending rate, it reduces or retards investment as well as economic growth, while a reduction in Lending rate would promote and stimulate economic growth in Nigeria. 
ii. The government should find a way of making the Treasury bill rate more attractive to the investing public, which will improve their subscription towards the government securities and ultimately improve government revenue and, translates to government meeting its public expenditure as at when due.

\section{REFERENCES}

[1] Acha, I. A. and Acha, C. K. (2011). Interest rate in Nigeria: An analytical perspective. Research Journal of Finance and Accounting, 2(3), 71-81.

[2] Fatoumata, K. M. (2017). Impact of Interest Rate on Economic Growth in Nigeria. Pyrex Journal of Business and Finance Management Research, 3(3), 98-111

[3] Kiragu, M. W. (2015). The impact of Treasury Bond Market Development on Economic growth in Kenya.

[4] Lyndon, M. \& Peter, E. (2016). The Relationship between Interest Rate and Economic Growth in Nigeria: An Error
Correction Model (ECM) Approach. International Journal of Economics and Financial Research, 2(6), 2411-9407

[5] Obamuyi, T. M. \& Olorunfemi, S. (2011). Financial Reforms, Interest Rate Behaviour and Economic Growth in Nigeria. Journal of Applied Finance and Banking, 1(4), 39-55.

[6] Obamuyi, T. M. (2009). An Investigation of The Relationship Between Interest Rates and Economic Growth in Nigeria. Journal of Economics and International Finance, 1(4), 93-98

[7] Rechard, O. (2018). Effect of Interest Rate Mechanisms on the Economic Development of Nigeria, 1986 -2016. IIARD International Journal of Economics and Business Management, 4(4), $91-115$

[8] Udoka, C. O. and Roland, A. A. (2012). The effect of interest rate fluctuation on the economic growth of Nigeria, 1970-2010. International Journal of Business and Social Science, 3(20), 295-302.

[9] Utile, B. J., Okwori, A. O. \& Ikpambese, M. D. (2018). Effect of Interest Rate on Economic Growth in Nigeria. International Journal of Advanced Academic Research of Social and Management Sciences, 4(1), 66-76 